\title{
The Molecular Nature of the Hydrophilic Sulfur Prepared from Aqueous Sulfide and Sulfite (Selmi Sulfur Sol) [1]
}

\author{
Ralf Steudel*, Thomas Göbel, and Gabriele Holdt \\ Institut für Anorganische und Analytische Chemie der Technischen Universität Berlin. \\ Sekr. C2, D-1000 Berlin 12 \\ Z. Naturforsch. 44b, 526-530 (1989); received January 20, 1989 \\ Sulfur Sol, Polythionates, Elemental Sulfur, Wackenroder Reaction \\ Hydrophilic sulfur sols prepared by reaction of aqueous sulfide and sulfite at low $\mathrm{pH}$ have been \\ studied by chemical analysis, ion-pair chromatography, and reversed-phase HPLC. The approxi- \\ mate composition of the sol is $x\left(\mathrm{NaHSO}_{4} / \mathrm{Na}_{2} \mathrm{SO}_{4}\right) \cdot y \mathrm{~S}_{n} \cdot z \mathrm{Na}_{2} \mathrm{~S}_{m} \mathrm{O}_{6}$ with $n=6-10$ and $m=4-16$. \\ The elemental sulfur $\mathrm{S}_{n}$ accounts for $17 \%$ and the polythionate sulfur for $10 \%$ of the dry weight \\ (sulfate: $18 \%$ ). On aging of the sol at $20^{\circ} \mathrm{C}$ the long-chain polythionates decompose to elemental \\ sulfur and tetrathionate as well as pentathionate. The higher chemical reactivity of this sol \\ compared to $\mathrm{S}_{8}$ is explained by the fact that $45 \%$ of the zero oxidation state sulfur $\left(\mathrm{S}^{\circ}\right)$ are present \\ as non- $\mathrm{S}_{8}$ molecules.
}

\section{Introduction}

Elemental sulfur is often used as a substrate for certain sulfur bacteria which take advantage of the energy released on oxidation of $\mathrm{S}^{\circ}$ to sulfate either to support their metabolism or to reduce carbon dioxide [2]. Various allotropes of elemental sulfur are of different reactivity [3]. Orthorhombic $\mathrm{S}_{8}\left(\alpha-\mathrm{S}_{8}\right)$ obtained by recrystallization of commercial sulfur from carbon disulfide will be least reactive because it is the most stable allotrope. Commercial elemental sulfurs are always mixtures of $\mathrm{S}_{8}$ with traces of $\mathrm{S}_{7}$, and sometimes $\mathbf{S}_{6}, \mathrm{~S}_{9}, \mathrm{~S}_{12}$, as well as polymeric sulfur $\left(\mathrm{S}_{\infty}\right)$ are present also [4]. Pure polymeric, insoluble sulfur can be obtained commercially or is prepared by repeated extraction of flowers of sulfur or of quenched liquid sulfur with $\mathrm{CS}_{2}$ at $20^{\circ} \mathrm{C}[5]$. These forms of sulfur are more reactive than $\alpha-\mathrm{S}_{8}$, but they are all hydrophobic and practically insoluble in water. The solubility of $\alpha$-S $\mathrm{S}_{8}$ in water at $25^{\circ} \mathrm{C}$ amounts to $5 \mu \mathrm{g} / \mathrm{l}$ [6]. However, in the presence of surfactants a considerably higher solubility of $\mathrm{S}_{8}$ in $\mathrm{H}_{2} \mathrm{O}$ is observed [7]. Truly hydrophilic sulfur can be prepared by two kinds of reactions, in which chains and rings of $\mathrm{S}$ atoms are built up from compounds containing only one or two $S$ atoms:

a) Acid decompositions of aqueous thiosulfate under suitable conditions yields hydrophilic sulfur, which can be peptized in water to yield colloidal solu-

\footnotetext{
* Reprint requests to Prof. Dr. R. Steudel.

Verlag der Zeitschrift für Naturforschung, D-7400 Tübingen 0932-0776/89/0500-0526/\$01.00/0
}

tions known as Raffo sols [8-10]. The particles of such solutions consist of long-chain polythionates $\left(\mathrm{S}_{m} \mathrm{O}_{6}^{2-}\right)$ and, to a smaller percentage, of elemental sulfur mostly in the form of $S_{8}$ [8]. These particles reach diameters of up to $0.2 \mu \mathrm{m}[11,12]$ and are probably composed of micelles and vesicles of polythionate anions, in which some $\mathrm{S}_{8}$ and other sulfur ring molecules are dissolved $[8,13]$.

b) The reaction of $\mathrm{H}_{2} \mathrm{~S}$ with $\mathrm{SO}_{2}$ in water at $\mathrm{pH}$ values below 7 yields a variety of polysulfur compounds [14] including elemental sulfur, polythionates [15], and polysulfuroxides [16] (later termed as polysulfane oxides [17]). Colloidal solutions of this hydrophilic sulfur are known as Selmi sols [10] and can conveniently be prepared according to Janek [18] from $\mathrm{Na}_{2} \mathrm{~S}, \mathrm{Na}_{2} \mathrm{SO}_{3}$, and $\mathrm{H}_{2} \mathrm{SO}_{4}$.

In this work we report for the first time a detailed analytical characterization of Selmi sulfur sols, prepared after Janek [18], using modern techniques.

\section{Results [19]}

Preparation of the sulfur sol [18]: $3.6 \mathrm{~g}$ of dry sodium sulfite and $6.4 \mathrm{~g}$ of sodium sulfide (" $\mathrm{Na}_{2} \mathrm{~S} \cdot 9 \mathrm{H}_{2} \mathrm{O}$ ") are dissolved in $50 \mathrm{ml}$ demineralized water each. $1.5 \mathrm{ml}$ of the freshly prepared $\mathrm{Na}_{2} \mathrm{SO}_{3}$ solution are mixed with the $\mathrm{Na}_{2} \mathrm{~S}$ solution, and a mixture of $2.7 \mathrm{~g}$ of conc. $\mathrm{H}_{2} \mathrm{SO}_{4}(1.47 \mathrm{ml}$ of $95-97 \% \mathrm{H}_{2} \mathrm{SO}_{4}$, density $\left.1.84 \mathrm{~g} \cdot \mathrm{cm}^{-3}\right)$ and $10 \mathrm{ml}$ $\mathrm{H}_{2} \mathrm{O}$ is added dropwise and with stirring as long as no permanent turbidity is observed (ca. $8-9 \mathrm{ml}$ are needed). Some $\mathrm{H}_{2} \mathrm{~S}$ is evolved and the temperature of the mixture rises to a maximum of $30^{\circ} \mathrm{C}$ (solution 
A). To the above mentioned $\mathrm{Na}_{2} \mathrm{SO}_{3}$ solution are added $3 \mathrm{ml}$ of conc. $\mathrm{H}_{2} \mathrm{SO}_{4}(95-97 \%)$, and this mixture is poured rapidly and with vigorous stirring into solution A resulting in a solution temperature of $c a$. $32{ }^{\circ} \mathrm{C}$. After standing of this mixture for $1 \mathrm{~h}$ at $20{ }^{\circ} \mathrm{C}$ the precipitate formed is collected on a folded paper filter, washed with $100 \mathrm{ml}$ water from the outside of the filter (!), and suspended in $300 \mathrm{ml}$ demineralized water. The resulting yellowish transparent suspension showed a $\mathrm{pH}$ of 2.5 , which did not change on storage for at least 7 days.

Analytical composition: $20 \mathrm{ml}$ of the freshly prepared sol were evaporated to dryness and the residue dried in a vacuum over phosphorus pentoxide. The yellow material formed $(69 \mathrm{mg})$ showed the lines of $\mathrm{S}_{8}$ at $473,439,249,218,187,153$, and $84 \mathrm{~cm}^{-1}$ in the Raman spectrum [20] and the absorptions of sulfate and hydrogensulfate $\left(\mathrm{HSO}_{4}^{-}\right)$in the infrared spectrum. The Raman spectrum of the liquid sol also showed the strongest lines of $S_{8}$ at 485,220 , and $152 \mathrm{~cm}^{-1}$ and no other compounds. On heating of the evaporation residue to $600{ }^{\circ} \mathrm{C}$ for $2 \mathrm{~h}$ in air a colorless salt was obtained the infrared spectrum of which was identical to that of $\mathrm{Na}_{2} \mathrm{SO}_{4}$ and the mass of which $(17.1 \mathrm{mg})$ corresponded to a sodium content of $18 \%$ by weight in the evaporated sol.

Titration of the aqueous sulfur sol with barium perchlorate resulted in a value of $18.1 \% \mathrm{~S}$ present as sulfate, while the total sulfur content was found by oxidation of the sol with bromine followed by $\mathrm{Ba}\left(\mathrm{ClO}_{4}\right)_{2}$ titration as $45.1 \%$. Consequently, $45.1-$ $18.1=27.0 \%$ of the material must be sulfur other than sulfate (e.g., elemental sulfur or polythionates).

The elemental sulfur content of the sol was determined by reversed-phase high-pressure liquid chromatography [21]. $20 \mathrm{ml}$ of the freshly prepared sol were magnetically stirred with $200 \mathrm{ml}$ of either cyclohexane or carbondisulfide, and after certain time intervals small samples of the organic phase were removed by a syringe and analyzed for sulfur rings $S_{n}$ by HPLC. The data given in Table 1 show that after $1.5 \mathrm{~h}$ extraction time $12.0 \mathrm{mg}$ of $\mathrm{S}_{n}(n=6$, $7,8)$ per $20 \mathrm{ml}$ of sol were determined which corresponds to an elemental sulfur content in the evaporated sol of $17 \%$ by weight. The slow increase of the $\mathrm{S}_{n}$ concentrations on longer extraction times is probably caused by formation of $S_{n}$ from long-chain polythionates (see below). In addition to $\mathrm{S}_{6}, \mathrm{~S}_{7}$, and $\mathrm{S}_{8}$ small amounts of $\mathrm{S}_{9}$ and $\mathrm{S}_{10}$ could also be detected (see Fig. 1).

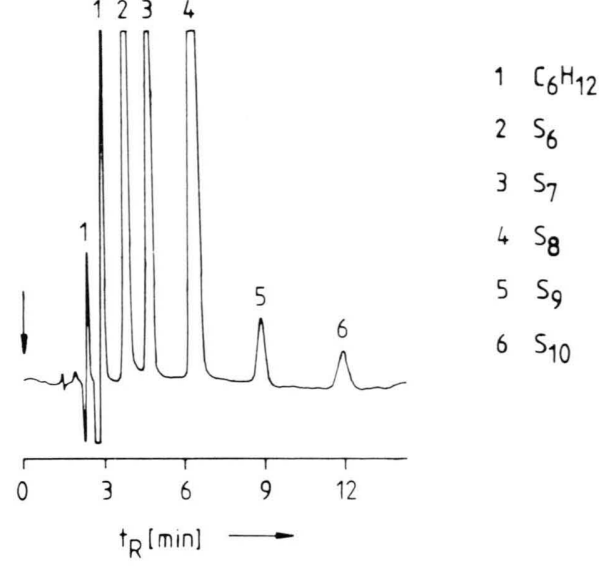

Fig. 1. Chromatogram (HPLC) of the cyclohexane extract of the sulfur sol prepared after Janek showing the presence of sulfur rings $\mathrm{S}_{n}(n=6-10)$. Extraction time $117.5 \mathrm{~h}$, flow $2.0 \mathrm{ml} / \mathrm{min}$, ordinate: UV absorption at $254 \mathrm{~nm}$.
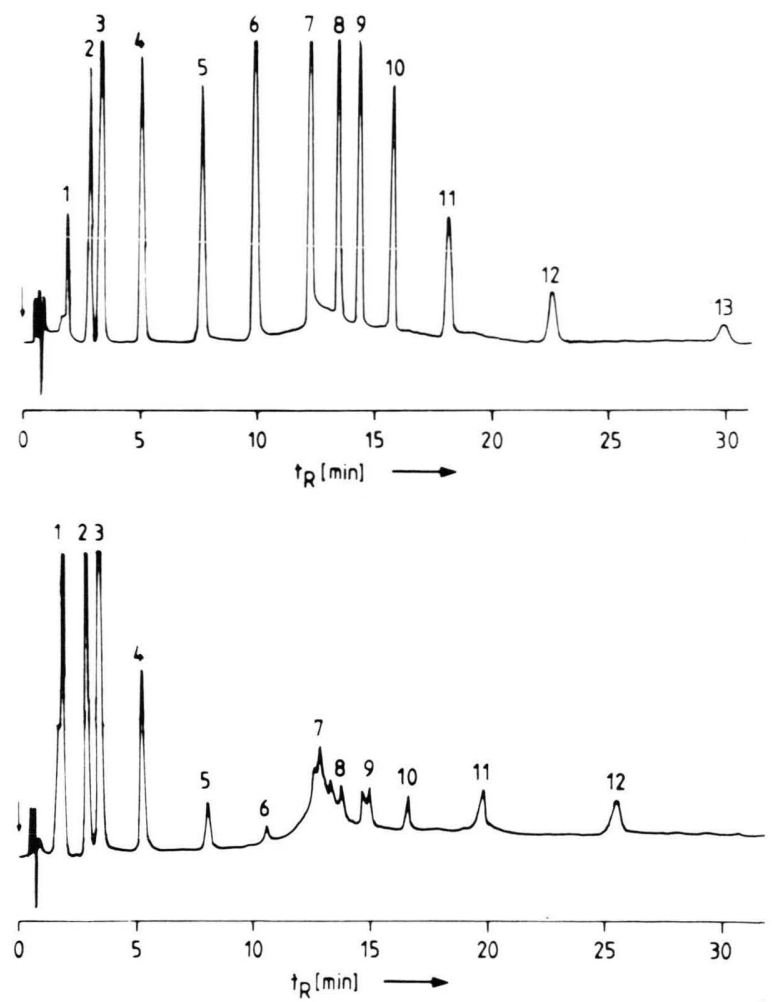

Fig. 2. Chromatograms of an aqueous sulfur sol prepared after Janek and showing the presence of thiosulfate (peak nr. 1) and polythionates (peaks 2-13; the peak number gives the number of zero oxidation state sulfur atoms in the molecule, e.g. peak 4 = hexathionate). Above: freshly prepared sol, below: sol after aging at $20{ }^{\circ} \mathrm{C}$ for $168 \mathrm{~h}$. Ordinate: UV absorbance at $254 \mathrm{~nm}$, flow $1 \mathrm{ml} / \mathrm{min}$. 
Table I. Extraction of elemental sulfur from Janek's sulfur sol by two different solvents as a function of the extraction time $\mathrm{t}$. Values (in $\mathrm{mg}$ ) determined by HPLC analysis.

\begin{tabular}{rccccccccc}
\hline $\mathrm{t}(\mathrm{h})$ & \multicolumn{3}{c}{ Cyclohexane } & \multicolumn{4}{c}{ Carbondisulfide } \\
\hline & $\mathrm{S}_{6}$ & $\mathrm{~S}_{7}$ & $\mathrm{~S}_{8}$ & $\sum \mathrm{S}_{n}$ & $\mathrm{~S}_{6}$ & $\mathrm{~S}_{7}$ & $\mathrm{~S}_{8}$ & $\Sigma \mathrm{S}_{n}$ \\
\hline 1.5 & 1.4 & 0.7 & 9.9 & 12.0 & 1.3 & 0.7 & 10.0 & 12.0 \\
18.5 & 1.5 & 0.7 & 11.0 & 13.2 & 1.5 & 1.3 & 11.8 & 14.5 \\
93.5 & 1.5 & 0.7 & 11.2 & 13.4 & 1.5 & 0.8 & 11.2 & 13.5 \\
117.5 & 1.5 & 0.8 & 11.4 & 13.6 & 1.5 & 1.2 & 11.7 & 14.3 \\
\hline
\end{tabular}

Analysis of the aqueous sulfur sol by ion-pair chromatography $[8,22,23]$ using a UV absorbance detector revealed the presence of thiosulfate and polythionates $\mathrm{S}_{m} \mathrm{O}_{6}^{2-}$ with up to 16 sulfur atoms per molecule. The composition very much depended on the age of the sample (see Fig. 2). The freshly prepared sol contained considerable concentrations of higher polythionates, but only traces of thiosulfate. After aging at $20^{\circ} \mathrm{C}$ for $168 \mathrm{~h}$, the concentrations of polythionates with more than 5 sulfur atoms had dramatically decreased, while those of thiosulfate, tetra- and pentathionate had increased. Since the concentration of elemental sulfur $\left(\mathrm{S}_{n}\right)$ as determined by HPLC (see Table I) simultaneously increased, it is assumed that a decomposition according to equations (1) and (2) takes place on aging:

$$
\begin{aligned}
& 2 \mathrm{~S}_{m} \mathrm{O}_{6}^{2-} \rightarrow \mathrm{S}_{m-x} \mathrm{O}_{6}^{2-}+\mathrm{S}_{m+x} \mathrm{O}_{6}^{2-} \\
& \mathrm{S}_{m} \mathrm{O}_{6}^{2-} \rightarrow \mathrm{S}_{m-n} \mathrm{O}_{6}^{2-}+\mathrm{S}_{n}(n=6-10)
\end{aligned}
$$

A quantitative evaluation [22] of the upper chromatogram in Fig. 2 showed that the freshly prepared sol contained $0.2 \mathrm{mg} \mathrm{S}_{2} \mathrm{O}_{3}^{2-}, 1.0 \mathrm{mg} \mathrm{S}_{4} \mathrm{O}_{6}^{2-}$, and $0.7 \mathrm{mg} \mathrm{S}_{5} \mathrm{O}_{6}^{2-}$ per $20 \mathrm{ml}$. After aging for $118 \mathrm{~h}$ the tetrathionate concentration had increased to $1.4 \mathrm{mg}$ and pentathionate to $1.5 \mathrm{mg}$ per $20 \mathrm{ml}$. The concentrations of the other polythionates were not determined, but from the sulfur balance it can be calculated that $\mathrm{ca}$. $10 \%$ of the dry mass or $22 \%$ of the total sulfur must be present as sulfur in oxyanions except sulfate:

sodium: $18 \%$, total sulfur: $45 \%$, sulfate: $18 \%$, elemental sulfur: $17 \%$, sulfur in oxyanions except sulfate: $10 \%$ (all data by weight).

\section{Discussion}

Our results indicate that the composition of the Selmi sulfur sol prepared after Janek can approximately be described by the formula $x\left(\mathrm{NaHSO}_{4} /\right.$
$\left.\mathrm{Na}_{2} \mathrm{SO}_{4}\right) \cdot y \mathrm{~S}_{n} \cdot z \mathrm{Na}_{2} \mathrm{~S}_{m} \mathrm{O}_{6}(n=6-10, m=4-16)$. Within the limits of accuracy, the sulfur balance is in accord with the ratio $x: y: z=2: \frac{2}{n}: \frac{1}{m}$. By dialysis the sodium hydrogensulfate and the lower polythionates as well as sulfite and thiosulfate are removed and the purified sol is composed of elemental sulfur and long-chain polythionates [24]. In Janek's sulfur sol [18] the sulfur atoms in the zero oxidation state $\left(\mathrm{S}^{\circ}\right)$ are distributed between $\mathrm{S}_{n}$ and $\mathrm{S}_{m} \mathrm{O}_{6}^{2-}$ in an approximate ratio of $2: 1$. Since $c a .45 \%$ of this $\mathrm{S}^{\circ}$ is present in a form other than $S_{8}$, the sulfur sol will be more reactive than $\mathrm{S}_{8}$. It has been suspected for a long time [25] that the polythionate anions are bound to the surface of the elemental sulfur particles by hydrophobic interaction thus generating a hydrophilic particle with a hydrophobic nucleus. This nucleus may be in a liquid state since it contains $\mathrm{S}_{6}, \mathrm{~S}_{7}, \mathrm{~S}_{9}$, and $S_{10}$ besides $S_{8}$ as does liquid sulfur [26]. This model resembles the micelle model proposed for the particles in Raffo sulfur sols prepared by acid decomposition of sodium thiosulfate [8]. This latter type of sol, however, prepared after Weitz et al. [9] has a much higher polythionate content than the Selmi sol prepared after Janek. This may be the reason that the Raffo sols are thermally more stable than the Selmi sol which tends to precipitate elemental sulfur more rapidly.

Neither in the case of the Selmi nor of the Raffo sols is there any indication for the formation of polysulfane oxides with structural units like $-\mathrm{S}-\mathrm{S}-\mathrm{S}-$ Ö

$[16,17]$. These compounds are of deep yellow color and form $\mathrm{S}_{2} \mathrm{O}$ on pyrolysis in vacuo [17], but neither an evaporated Raffo sol nor polythionates yielded $\mathrm{S}_{2} \mathrm{O}$ on heating in vacuo. The polysulfane oxides are obviously only obtained when the reaction between $\mathrm{H}_{2} \mathrm{~S}$ and $\mathrm{SO}_{2}$ takes place at low temperatures and with an excess of $\mathrm{SO}_{2}[16,17]$, while the Selmi sol has been prepared at $c a .30{ }^{\circ} \mathrm{C}$ in this work. On the other hand, it is obvious now that the so-called "Wackenroder sulfur" obtained from $\mathrm{H}_{2} \mathrm{~S}$ and $\mathrm{SO}_{2}$ in water at $0{ }^{\circ} \mathrm{C}$ is a mixture of elemental sulfur $\left(\mathrm{S}_{n}\right)$, polysulfane oxides and long-chain polythionates. The latter compounds are responsible for the hydrophilic nature of this material. The presence of polythionates or polythionic acids in the "sulfur" precipitated from cold reaction mixtures of $\mathrm{H}_{2} \mathrm{~S}$ and $\mathrm{SO}_{2}$ in water follows not only from the analytical composition (S : $c a$. $88 \%, \mathrm{H}: \mathrm{ca} .1 \%$, oxygen being the rest) but also from infrared spectra showing absorptions at 610 , 
$640,1020,1045$, and $1220-1235 \mathrm{~cm}^{-1}$ [27], all typical for long-chain polythionates [8]. In addition, the polysulfaneoxide absorption at $1120-1130 \mathrm{~cm}^{-1}$ [27] is observed, which is to be assigned to $v(\mathrm{SO})$ of the unit $-\mathrm{S}-\mathrm{S}(\mathrm{O})-\mathrm{S}-[28]$.

One common feature of the hydrophilic sulfur sols is the presence of considerable concentrations of $\mathrm{S}_{6}$, $\mathrm{S}_{7}, \mathrm{~S}_{9}$, and $\mathrm{S}_{10}$, which are unstable in the presence of water. We believe that these species are dissolved in the probably liquid nucleus of the sol particles and are thus protected from the water by the polythionate anions which cover the particle surface. This view is supported by our observation that stirring of $10 \mathrm{ml}$ of a Raffo sol [8] with $80 \mathrm{mg}$ of solid $\mathrm{S}_{7}$ at either $20^{\circ} \mathrm{C}$ or $50{ }^{\circ} \mathrm{C}$ resulted in a dramatic increase of the $\mathrm{S}_{7}$ concentration inside the sol particles within 20-60 min. The analysis was performed by HPLC after filtration through a $0.45 \mu \mathrm{m}$ filter which the sol particles can pass but not the solid $\mathrm{S}_{7}$.

Summarizing, it can be stated that hydrophilic sulfur sols are composed of elemental sulfur $\mathrm{S}_{n}(n=$ $6 \cdots 10)$ and polythionates $\mathrm{S}_{m} \mathrm{O}_{6}(m=4 \cdots 16)$ in varying proportions depending on the preparation and the age of the sol. The thermal stability of the sol depends on the $\mathrm{S}_{n} / \mathrm{S}_{m} \mathrm{O}_{6}^{2-}$ ratio, since the polythionates keep the elemental sulfur in solution. Sulfur sols are easy to prepare and provide a kind of zero oxidation state sulfur which is more reactive than $\mathrm{S}_{8}$ and, in addition, hydrophilic.

\section{Experimental}

The experimental technique as well as the chromatographic equipment have been described elsewhere $[8,21,22]$. The chemicals used were of highest available purity. Reversed-phase HPLC analysis of sulfur rings was performed using Waters $10 \mathrm{C} 18$ Radial-Pak columns contained in an MC 100 compression module and methanol as an eluent. The separation of the polythionates was achieved with a Chrompak C18 glass column (particle size $5 \mu \mathrm{m}$ ) and an eluent mixture of $27 \%$ acetonitrile (by volume), $73 \%$ doubly distilled water, $2 \mathrm{mmol} / \mathrm{l}$ tetrabutylammoniumhydrogenphosphate, and $1 \mathrm{mmol} / \mathrm{l}$ sodium carbonate applying a gradient procedure [23].

The Raman spectrometer [29] as well as the preparation of reference compounds for the peak identification and the calibration of the chromatographic systems have also been described earlier $[22,30]$.

We are grateful to the Deutsche Forschungsgemeinschaft and the Verband der Chemischen Industrie for financial support.
[1] Part 126 of the Series on Sulfur Compounds; for part 125 see R. Steudel, T. Göbel, H. Schmidt, and G. Holdt, Fresenius' Z. Anal. Chem., in print.

[2] For reviews see, e.g., U. Fischer in H.-J. Rehm and G. Reed (eds): Biotechnology, Vol. 6b, Chapter 15, p. 463, VCH Verlagsgesellschaft, Weinheim (1988); J. A. Cole and S. J. Ferguson (eds): The Nitrogen and Sulphur Cycles, Cambridge University Press, Cambridge (1988); H. G. Trüper, in A. Müller and B. Krebs (eds): Sulfur - Its Significance for Chemistry, for the Geo-, Bio-, and Cosmosphere and Technology, p. 351, Elsevier Publ. Co., Amsterdam (1984); L. M. Siegel in D. M. Greenberg (ed.): Metabolism of Sulfur Compounds, Chapt. 7, p. 217, Academic Press, New York (1975); M. Bothe and A. Trebst (eds): Biology of Inorganic Nitrogen and Sulfur, Springer-Verlag, Berlin (1981).

[3] F. Fehér and D. Kurz, Z. Naturforsch. 24b, 1089 (1969); P. D. Bartlett and R. E. Davis, J. Am. Chem. Soc. 80, 2513 (1958).

[4] R. Steudel and B. Holz, Z. Naturforsch. 43b, 581 (1988).

[5] R. Steudel, S. Paßlack-Stephan, and G. Holdt, Z. Anorg. Allg. Chem. 517, 7 (1984) and references cited therein.

[6] J. Boulege, Phosphorus Sulfur 5, 127 (1978).
[7] R. Steudel and G. Holdt, Angew. Chem. 100, 1409 (1988); Angew. Chem., Int. Ed. Engl. 27, 1358 (1988).

[8] R. Steudel, T. Göbel, and G. Holdt, Z. Naturforsch. 43b, 203 (1988).

[9] E. Weitz, K. Gieles, J. Singer, and B. Alt, Chem. Ber. 89, 2365 (1956).

[10] Reviews: Gmelin Handbuch der Anorganischen Chemie, 8. Auflage, Schwefel, Teil A, Lieferung 2, p. 486-501, Verlag Chemie, Weinheim (1953); S. Odén, Der Kolloide Schwefel, Nova Acta Regiae Soc. Sci. Upsaliensis, Ser. IV, Vol. 3, Nr. 4, Upsala (1913).

[11] E. M. Zaiser and V. K. LaMer, J. Colloid. Sci. 3, 571 (1948); V. K. LaMer and I. Johnson, J. Am. Chem. Soc. 67, 2055 (1945); A. S. Kenyon and V. K. LaMer, J. Colloid Sci. 4, 163 (1948).

[12] M. Kerker, E. Daby, G. L. Cohen, J. P. Kratohvil, and E. Matijević, J. Phys. Chem. 67, 2105 (1963).

[13] R. Steudel, in H. G. Schlegel and B. Bowien (eds): Biology of Autotrophic Bacteria, Chapter 16, Sci. Tech. Publ., Madison (USA) (1989).

[14] Gmelin Handbuch der Anorganischen Chemie, 8. Auflage, Schwefel, Teil A, Lieferung 2, p. 254-257, and Teil B2, p. 976, 980, 993, 1012, 1025, Verlag Chemie, Weinheim (1953) and (1960). 
[15] E. Blasius and R. Krämer, J. Chromatogr. 20, 367 (1965); E. Blasius and W. Burmeister, Z. Anal. Chem. 168, 1 (1959); E. Blasius and H. Thiele, Z. Anal. Chem. 197, 347 (1963).

[16] P. W. Schenk and W. Kretschmer. Angew. Chem. 74, 695 (1962); W. Kretschmer, Diplomarbeit, Freie Univ. Berlin (1962).

[17] P. W. Schenk and R. Steudel, Angew. Chem. 77, 437 (1965): Angew. Chem., Int. Ed. Engl. 4, 402 (1965); P. W. Schenk, R. Steudel, and J. Bilal, Z. Anorg. Allg. Chem. 353, 250 (1967).

[18] A. Janek, Kolloid-Z. 64, 31 (1933); see also S. S. Gupta and S. Ghosh, Proc. Nat. Acad. Sci. India 43 A, 109 (1973).

[19] For more details see T. Göbel, Dissertation, Techn. Univ. Berlin (1988).

[20] R. Steudel and H.-J. Mäusle, Z. Naturforsch. 33a, 951 (1978).

[21] R. Steudel, H.-J. Mäusle, D. Rosenbauer, H. Möckel, and T. Freyholdt, Angew. Chem. 93, 402 (1981); Angew. Chem., Int. Ed. Engl. 20, 394 (1981); R. Strauss and R. Steudel, Fresenius' Z. Anal. Chem. 326, 543 (1987).

[22] R. Steudel and G. Holdt, J. Chromatogr. 361, 379 (1986).

[23] R. Steudel, G. Holdt, T. Göbel, and W. Hazeu, Angew. Chem. 99, 143 (1987); Angew. Chem., Int. Ed. Engl. 26, 151 (1987).

[24] Selmi sols not containing $\mathrm{Na}_{2} \mathrm{SO}_{4}$ can of course be obtained from $\mathrm{H}_{2} \mathrm{~S}$ and aqueous $\mathrm{SO}_{2}$.

[25] E. O. K. Verstraete, Kolloid-Z. 102, 25, 251 (1943).

[26] R. Steudel, R. Strauss, and L. Koch, Angew. Chem. 97, 58 (1985); Angew. Chem., Int. Ed. Engl. 24, 59 (1985).

[27] M. Töpert, Diplomarbeit, Freie Univ. Berlin (1964); R. Ludwig, Diplomarbeit, Techn. Univ. Berlin (1965) and Dissertation, Techn. Univ. Berlin (1969).

[28] R. Steudel, Z. Naturforsch. 25b, 156 (1970).

[29] R. Steudel, D. Jensen, and B. Plinke, Z. Naturforsch. 42b, 163 (1987).

[30] R. Steudel, Top. Curr. Chem. 102, 149 (1982). 